\title{
The Impact of the Coronavirus Pandemic on Global Hedge Funds
}

\author{
Dan Qian ${ }^{1, *}$ \\ ${ }^{1}$ W. P. Carey School of Business, Arizona State University, Business Administration, 300 E Lemon St, Tempe, AZ, \\ 85287, United States \\ *Email:dqian5@asu.edu
}

\begin{abstract}
The paper examines whether the coronavirus pandemic has affected selected hedge fund markets (Eurekahedge Hedge Fund Index, Eurekahedge North American Hedge Fund Index, Eurekahedge European Hedge Fund Index, Eurekahedge Asian Hedge Fund Index). The purpose of the paper is to assess the degree of the differential impact of the coronavirus pandemic on selected hedge fund markets. This paper collects hedge fund market index performance data one year before and after the coronavirus pandemic was discovered and analyzed the data through the t-test. The results show that the return of the hedge fund market during the coronavirus pandemic outperformed that of the hedge fund market without the coronavirus pandemic. The data of the Asian and North American markets are particularly obvious, but the performance of the European market is not particularly obvious. This paper guides participants in the hedge fund market on how to make safer and more profitable investments during the coronavirus pandemic, and it also provides directions for further research.
\end{abstract}

Keywords: the coronavirus pandemic, Eurekahedge Hedge Fund Index, T-Test.

\section{INTRODUCTION}

The World Health Organization announced the discovery of the coronavirus in January 2020. The outbreak of the coronavirus pandemic has caused economic instability and challenges to participants [1]. The new coronavirus pandemic poses a threat to human health and has an impact on the global economy. Global supply chains were affected to varying degrees before and during the pandemic. The article also mentioned that maritime trade accounts for about $80 \%$ of international trade. The coronavirus pandemic causes the interruption of import and export trade between countries. This has also exacerbated the instability and instability and risk of the hedge fund market. 700 billion US dollars may reduce the external private funds entering developing economies in 2020. Compared with the level in 2019 , it is $60 \%$ higher than the direct impact of the 2008 global financial crisis. The new crown pneumonia epidemic has led to a series of consequences such as the rise in the level of the national debt, the reduction of economic activities, the impact of resource mobilization, and the decline in the proportion of private financing [2].
The purpose of this paper is to examine whether the coronavirus pandemic has had beneficial or harmful effects on selected hedge fund markets. The paper will use the t-test to analyze the data of Eurekahedge hedge fund index and yield, Eurekahedge North American hedge fund index and yield, Eurekahedge European hedge fund index and yield, Eurekahedge Asian hedge fund index and yield. Compared with 2019, the epidemic will have higher volatility and higher returns in the global and North American, European, and Asian stock markets throughout 2020. Therefore, it cannot be proved that the greater the volatility, the lower the returns of the hedge fund market because the returns of hedge funds are linked to the strategies of hedge fund managers. The greater the market volatility, the more favorable it is for hedge fund managers in certain specific circumstances. Hedge fund managers use part of their assets in stocks in non-cyclical industries. This decision can enable the return of noncyclical stocks to offset the loss of cyclical stocks, even in the event of an economic downturn. Compared with traditional stocks, hedge funds have greater risks and greater gains and losses with them. Because hedge funds can use the borrowed money to buy more assets, including derivatives such as options and futures, to increase their potential returns or losses [3], participants 
of hedge funds can improve their investment opportunity set by adding hedge funds or funds from the HF portfolio to different benchmark portfolios. As an asset class, investing in HF funds has indeed brought diversified returns to mean-variance investors [4].

The paper will be divided into three parts of literature review, data, and research methods. Empirical results will research the impact of the coronavirus pandemic on global hedge funds.

\section{LITERATURE REVIEW}

\subsection{Economic Environment under the Coronavirus Epidemic}

In a stable economic market, short-selling options, bond short-straddle options, the spread between highyield bonds and Treasury bonds, and the return of small market capitalization stocks are the four key factors that affect the return of hedge fund indexes. Hedge funds are also affected by fee structure, lock-in and restriction periods, leverage, fund size, and age. During the 2009 financial crisis, a sharp drop in the CISDM nonperforming securities index and CISDM and other weighted hedge fund indexes were sufficient for the risks and returns generated by hedge fund indexes when economic conditions were unstable. As a result, the troubled securities hedge funds performed poorly. It further proves that the success of troubled securities hedge funds is positively correlated with economic development [5-1]. However, the positive and negative returns of hedge funds and the strategies of hedge fund managers are also inextricably linked rather than completely linked to the market economy. It is undeniable that during the coronavirus pandemic, the global economic downturn has had a non-negligible impact on the hedge fund market [6].

\subsection{The Impact of Past Epidemics on the Market}

The coronavirus pandemic is not the first global pandemic [7]. The Severe Acute Respiratory Syndrome (SARS) from 2002 to 2004 was the same as the predecessor of the coronavirus. The virus pandemic has swept the world [8-1]. According to the "Centers for Disease Control and Prevention." in 2009 H1N1 PANDEMIC, the same thing happened with the 2009 H1N1 new influenza strain [5-2].

Past epidemics have had a huge and negative impact on global financial markets. For example, Severe Acute Respiratory Syndrome (SARS) severely hit East Asian economies. In the first quarter of 2003, the GDP growth of some East Asian economies slowed significantly. People's consumption expenditure has decreased, especially service consumption has dropped sharply. Schools are closed in Hong Kong, Singapore, and parts of China, meetings are postponed or unattended, and passenger traffic in restaurants and shopping malls has fallen. The tourism industry has also been hit hard. The decline in the number of tourists, the plummet in air travel and hotel occupancy rates have led to a decline in retail sales in East Asian economies. Hong Kong's service industry, business travel, and tourism account for approximately $80 \%$ of total GDP. Since the Severe Acute Respiratory Syndrome (SARS) outbreak, Hong Kong's unemployment rate has risen from $7.2 \%$ in January to 8.3 in May. \%. In China, there was an increase of more than $60 \%$ in March in a year, but it only increased by $18 \%$ in May of the same year. The tourism industry in Australia accounted for $4.5 \%$ of the economy, a decline of $2.6 \%$ in one month as of May 2003, and a decrease of $8.5 \%$ every April thereafter. Financial markets can minimize the risk of the coronavirus pandemic if we learn enough from past failures [8-2]. The impact of the new coronavirus on hedge funds can learn from the experience of past epidemics on hedge funds. Past experience can help hedge fund participants to continuously plan to think about the risks brought by the epidemic and how to avoid the impact of risks to the greatest extent [9].

\section{DATA AND RESEARCH METHODS}

\subsection{Data}

The data in the paper uses the hedge fund index from Eurekahedge. The data arrangements provide a complete data sample for testing to determine whether there is a significant difference between the two sets of means. The selection of hedge fund data takes the World Health Organization's announcement of the discovery of the coronavirus in January 2020 as the time node. The paper compares the Eurekahedge hedge fund index and yield for the entire year of 2019 and the Eurekahedge hedge fund index and yield for the entire year of 2020. To make a comparison; at the same time, the paper divides the region into the global market, the North American market, the European market, and the Asian market (Eurekahedge Hedge Fund Index and Yield, Eurekahedge North American Hedge Fund Index and Yield, Eurekahedge European Hedge Fund Index and Yield, Eurekahedge Asian Hedge Fund index and rate of return). 


\subsubsection{Line chart}

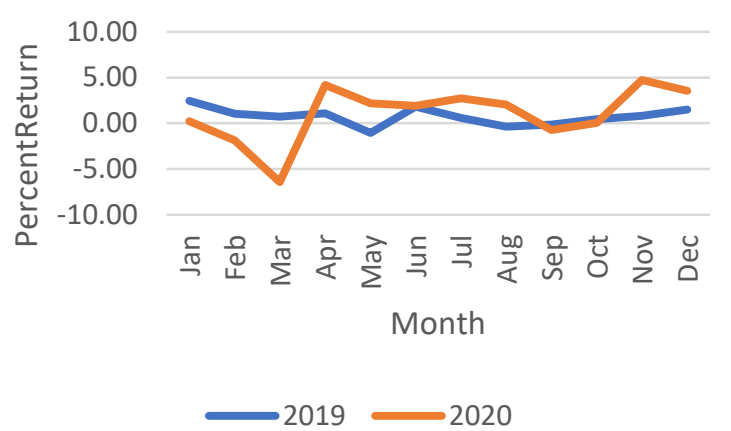

Figure 1. Line chart of global hedge fund yields in 2019 and 2020

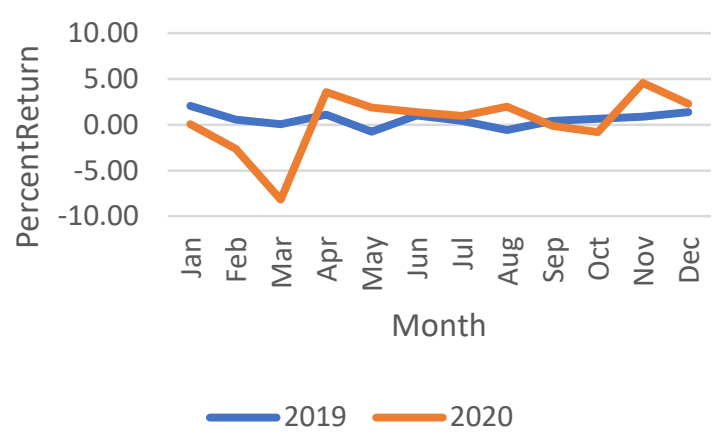

Figure 3. Line chart of North American hedge fund yields in 2019 and 2020

\subsection{Research Methods}

The paper uses the t-test to compare selected index and yield: Eurekahedge hedge fund index and yield, Eurekahedge North American hedge fund index and yield, Eurekahedge European hedge fund index and yield, Eurekahedge Asian hedge fund index and yield. All data comes from Eurekahedge.

$$
t=\frac{\overline{x_{1}}-\overline{x_{2}}}{s / \sqrt{n}}
$$

Where: $\overline{x_{1}}$ represents the average values of the first sets, $\overline{x_{2}}$ represents the average values of the second sample sets, $\mathrm{s}$ represents the standard deviation of the

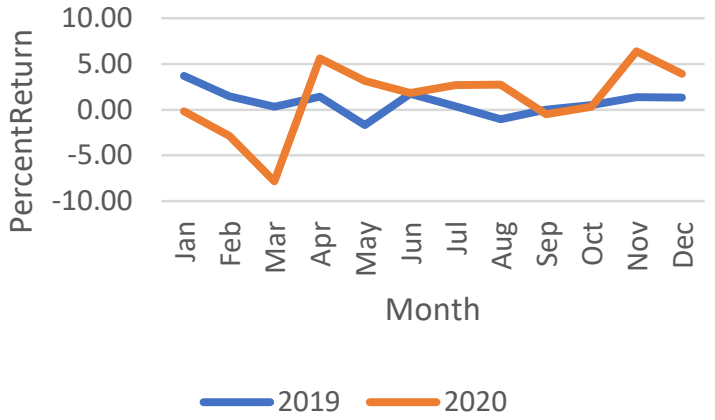

Figure 2. Line chart of European hedge fund yields in 2019 and 2020

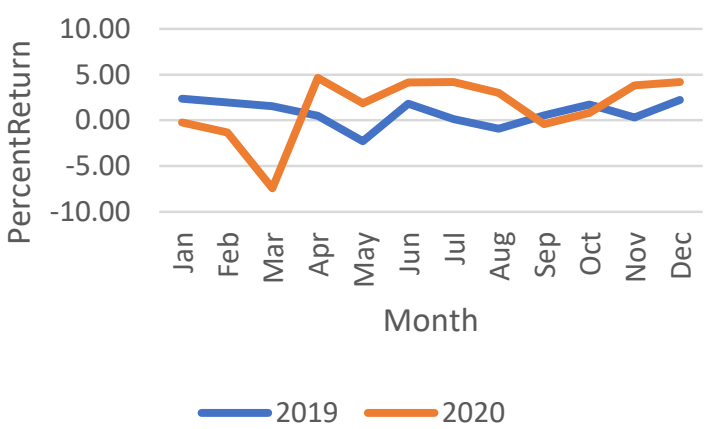

Figure 4. Line chart of Asian hedge fund yields in 2019 and 2020

difference between paired data values, and $\mathrm{n}$ represents the sample size (number of pairwise differences).

\section{EMPIRICAL RESULTS}

\subsection{T-Test: Paired Two-Sample Mean Analysis}

The paired t-tests for the significance of the eightsample means are shown in Table 1 to Table 8 . The test is performed at a specified probability level alpha $(\alpha)$ of $0.05(5 \%)$.

\subsubsection{Hedge Fund Indexes}

Table 1. Comparison of Global Hedge Fund Indexes in 2019 and 2020

\begin{tabular}{lrr}
\hline & 2019 & 2020 \\
\hline Mean & 478.7449 & 502.9465 \\
Variance & 71.9967 & 778.2627 \\
Observations & 12 & 12 \\
Pearson Correlation & 0.7808 & \\
Hypothesized Mean Difference & 0 & \\
df & 11 & \\
t Stat & -3.8242 \\
P(T<=t) one-tail & 0.0014 \\
t Critical one-tail & 1.7959 \\
P(T<=t) two-tail & 0.0028 \\
$t$ Critical two-tail & 2.2010 & \\
\hline
\end{tabular}


As shown in Table 1, the average value of Global Hedge Fund Indexes in 2019 is 478.7449 , and the average value in 2020 is 502.9465. Comparing these two values, it is concluded that the volatility of global stock markets in 2020 will be greater than that in 2019. $\mathrm{t}$ Stat of -3.8242 indicates that the performance of global stock markets in 2019 is worse than that in 2020 . The $\mathrm{P}(\mathrm{T}<=\mathrm{t})$ two-tail of Global Hedge Fund Index is 0.0028 , indicating that this statistic is statistically significant.

Table 2. Comparison of North American Hedge Fund Indexes in 2019 and 2020

\begin{tabular}{|c|c|c|}
\hline & 2019 & 2020 \\
\hline Mean & 548.2858 & 573.2674 \\
\hline Variance & 67.5610 & 1612.2902 \\
\hline Observations & 12 & 12 \\
\hline Pearson Correlation & 0.6870 & \\
\hline Hypothesized Mean Difference & 0 & \\
\hline$d f$ & 11 & \\
\hline t Stat & -2.4711 & \\
\hline $\mathrm{P}(\mathrm{T}<=\mathrm{t})$ one-tail & 0.0155 & \\
\hline t Critical one-tail & 1.7959 & \\
\hline$P(T<=t)$ two-tail & 0.0311 & \\
\hline t Critical two-tail & 2.2010 & \\
\hline
\end{tabular}

As shown in Table 2, the average value of North American Hedge Fund Indexes in 2019 is 548.2858, and the average value in 2020 is 573.2674 . Comparing these two values, it is concluded that the volatility of global stock markets in 2020 will be greater than that in 2019 .
The $t$ Stat of -2.4711 indicates that the North American stock market performed worse in 2019 than in 2020. The North American Hedge Fund Index's $\mathrm{P}(\mathrm{T}<=\mathrm{t})$ two-tail is 0.0311 , indicating that this statistic is statistically significant.

Table 3. Comparison of European Hedge Fund Indexes in 2019 and 2020

\begin{tabular}{|c|c|c|}
\hline & 2019 & 2020 \\
\hline Mean & 350.3069 & 351.7928 \\
\hline Variance & 27.1248 & 214.5006 \\
\hline Observations & 12 & 12 \\
\hline Pearson Correlation & 0.6339 & \\
\hline $\begin{array}{l}\text { Hypothesized Mean Difference } \\
\text { df } \\
\text { t Stat }\end{array}$ & $\begin{array}{r}0 \\
11 \\
-0.4275\end{array}$ & \\
\hline$P(T<=t)$ one-tail & 0.3386 & \\
\hline $\begin{array}{l}\text { t Critical one-tail } \\
\mathrm{P}(\mathrm{T}<=\mathrm{t}) \text { two-tail } \\
\text { t Critical two-tail }\end{array}$ & $\begin{array}{l}1.7959 \\
0.6772 \\
2.2010 \\
\end{array}$ & \\
\hline
\end{tabular}

As shown in Table 3, the average value of European Hedge Fund Indexes in 2019 is 350.3069 , and the average value in 2020 is 351.7928 . Comparing these two values, it is concluded that the volatility of global stock markets in 2020 will be greater than that in 2019. But there is no significant difference because there is only a difference of 1.4859 between the two. The $t$ Stat of -0.4275 indicates that the European stock market performed worse in 2019 than in 2020. The $\mathrm{P}(\mathrm{T}<=\mathrm{t})$ two-tail of the European Hedge Fund Index is 0.6772 , which means that it is not statistically significant because it exceeds the test's specified probability level alpha $(\alpha) 0.05$ (5\%).

Table 4. Comparison of Asian Hedge Fund Indexes in 2019 and 2020

\begin{tabular}{|c|c|c|}
\hline & 2019 & 2020 \\
\hline Mean & 406.1059 & 438.0822 \\
\hline Variance & 58.6465 & 1101.1028 \\
\hline Observations & 12 & 12 \\
\hline Pearson Correlation & 0.6427 & \\
\hline Hypothesized Mean Difference & 0 & \\
\hline$d f$ & 11 & \\
\hline t Stat & -3.8377 & \\
\hline $\mathrm{P}(\mathrm{T}<=\mathrm{t})$ one-tail & 0.0014 & \\
\hline t Critical one-tail & 1.7959 & \\
\hline $\mathrm{P}(\mathrm{T}<=\mathrm{t})$ two-tail & 0.0028 & \\
\hline t Critical two-tail & 2.2010 & \\
\hline
\end{tabular}


As shown in Table 4, the average value of Asian Hedge Fund Indexes in 2019 is 406.1059, and the average value in 2020 is 438.0822 . Comparing the two values, the value in 2020 is greater than the value of 2019. It is concluded that the volatility of global stock markets in 2020 will be greater than that in 2019. t Stat of -3.8377 indicates that the Asian stock market will perform better

Table 5. Comparison of Global Hedge Fund Yields in 2019 and 2020

\begin{tabular}{|c|c|c|}
\hline & 2019 & 2020 \\
\hline Mean & 0.7411 & 1.0456 \\
\hline Variance & 0.9137 & 9.5347 \\
\hline Observations & 12 & 12 \\
\hline Pearson Correlation & 0.0067 & \\
\hline Hypothesized Mean Difference & 0 & \\
\hline df & $\begin{array}{r}11 \\
-03270\end{array}$ & \\
\hline $\mathrm{P}(\mathrm{T}<=\mathrm{t})$ one-tail & 0.3749 & \\
\hline $\begin{array}{l}\text { t Critical one-tail } \\
\mathrm{P}(\mathrm{T}<=\mathrm{t}) \text { two-tail } \\
\text { t Critical two-tail }\end{array}$ & $\begin{array}{l}1.7959 \\
0.7498 \\
2.2010 \\
\end{array}$ & \\
\hline
\end{tabular}

From Table 5, we know that the average value of Global Hedge Fund Yields in 2019 is 0.7411 , the average value in 2020 is 1.0456 , and the $t$ Stat is -0.3270 . It means that the return of global hedge funds in 2020 is higher in 2020 than in 2019. The $\mathrm{P}(\mathrm{T}<=\mathrm{t})$ two-tail of the Asian Hedge Fund Index is 0.0028 , which indicates that the statistic is statistically significant.

\subsubsection{Hedge Fund yields} than in 2019. But $\mathrm{P}(\mathrm{T}<=\mathrm{t})$ one-tail is 0.3749 and $\mathrm{P}(\mathrm{T}<=\mathrm{t})$ two-tail is 0.7498 , which is greater than $0.05(5 \%)$ of the benchmark of the test performed at the alpha $(\alpha)$ level. The difference was not statistically significant.

Table 6. Comparison of North American Hedge Fund Yields in 2019 and 2020

\begin{tabular}{|c|c|c|}
\hline & 2019 & 2020 \\
\hline Mean & 0.7915 & 1.2744 \\
\hline Variance & 1.9487 & 15.1140 \\
\hline Observations & 12 & 12 \\
\hline Pearson Correlation & -0.0262 & \\
\hline Hypothesized Mean Difference & 0 & \\
\hline df & 11 & \\
\hline t Stat & -0.4016 & \\
\hline $\mathrm{P}(\mathrm{T}<=\mathrm{t})$ one-tail & 0.3478 & \\
\hline t Critical one-tail & 1.7959 & \\
\hline$P(T<=t)$ two-tail & 0.6956 & \\
\hline t Critical two-tail & 2.2010 & \\
\hline
\end{tabular}

From Table 6 , we know that the average return of North American hedge funds in 2019 is 0.7915 , the average for 2020 is 1.2744 , and the $\mathrm{t}$ Stat is -0.4016 . This means that North American hedge fund returns in 2020 will be higher than in 2019. But the difference between
$\mathrm{P}(\mathrm{T}<=\mathrm{t})$ one-tail is 0.3478 and $\mathrm{P}(\mathrm{T}<=\mathrm{t})$ two-tail is 0.6956 is greater than $0.05(5 \%)$ of the benchmark test performed at the alpha $(\alpha)$ level. The difference was not statistically significant.

Table 7. Comparison of European Hedge Fund Yields in 2019 and 2020

\begin{tabular}{lrr}
\hline & 2019 & 2020 \\
\hline Mean & 0.6097 & 0.4180 \\
Variance & 0.6174 & 11.1121 \\
Observations & 12 & 12 \\
Pearson Correlation & 0.1690 & \\
Hypothesized Mean Difference & 0 & 11 \\
df & 0.2017 & \\
t Stat & 0.4219 & \\
$P(T<=t)$ one-tail & 1.7959 & \\
t Critical one-tail & 0.8439 & \\
$P(T<=t)$ two-tail & 2.2010 & \\
t Critical two-tail & & \\
\hline
\end{tabular}


From Table 7, we know that the average European hedge fund yield in 2019 is 0.6097 , and the 2020 average is 0.4180 . This means that European hedge fund returns in 2020 will be lower than in 2019. However, $\mathrm{P}(\mathrm{T}<=\mathrm{t})$ one-tail is 0.4219 , and $\mathrm{P}(\mathrm{T}<=\mathrm{t})$ two-tail is 0.8439 , which is greater than $0.05(5 \%)$ of the benchmark test performed at the alpha $(\alpha)$ level. The difference was not statistically significant.

Table 8. Comparison of Asian Hedge Fund Yields in 2019 and 2020

\begin{tabular}{lrr}
\hline & 2019 & 2020 \\
\hline Mean & 0.8227 & 1.4307 \\
Variance & 1.9520 & 12.1727 \\
Observations & 12 & 12 \\
Pearson Correlation & -0.2558 & \\
Hypothesized Mean Difference & 11 & \\
df & -0.5167 \\
t Stat & 0.3078 \\
P $(T<=t)$ one-tail & 1.7959 \\
t Critical one-tail & 0.6156 & \\
$P(T<=t)$ two-tail & 2.2010 & \\
t Critical two-tail & & \\
\hline
\end{tabular}

From Table 8, we know that the average return of Asian hedge funds in 2019 is 0.8227 and the average in 2020 is 1.4307 . This means that the return of Asian hedge funds in 2020 is higher than in 2019. But $\mathrm{P}(\mathrm{T}<=\mathrm{t})$ onetail is 0.3078 and $\mathrm{P}(\mathrm{T}<=\mathrm{t})$ two-tail is 0.6156 , which is greater than $0.05(5 \%)$ in the benchmark of the test performed at the alpha $(\alpha)$ level, so the two the difference was not statistically significant.

\subsection{Summary}

The impact of the new crown pneumonia epidemic on the hedge fund market is not particularly large, according to the statistics of Eurekahedge Hedge Fund Index and Eurekahedge Hedge Fund Yields in the paper. The rate of return in the hedge fund market has a greater relationship with hedge fund managers because some hedge fund managers have a strategy that the greater the market volatility, the higher the returns. Hedge fund managers can buy undervalued stocks while selling short overvalued stocks to reduce the fund's risk. For example, hedge fund managers choose market-neutral strategies by adjusting their positions and increasing them overtime to earn the excess returns between the two sets of targets. Another solution is to offset market volatility by improving the risk-return relationship of the investment portfolio and reducing kurtosis during periods when stock returns are negative [10].

\section{CONCLUSION}

The paper examines whether the coronavirus pandemic has affected selected hedge fund markets and assesses the degree of impact by using the t-test on Hedge Fund Index and Hedge Fund Yields. The results show that the Hedge Fund Index and Hedge Fund Yields in the year after the outbreak of the coronavirus pandemic are better than the year before the outbreak of the coronavirus pandemic; it is positive for the hedge fund market when the stock market is volatile Impacted. The research conclusions of the paper provide directions for participants in the hedge fund market during the coronavirus pandemic and provide more powerful guidance for participants, as well as directions for further research. What is lacking in the research is that the data may be biased because the Hedge Fund Index and Hedge Fund Yields are not accurate to the day.

\section{REFERENCES}

[1] World Health Organization, Tracking sars-cov-2 variants. World Health Organization, n.d. https://www.who.int/en/activities/tracking-SARSCoV-2-variants/.

[2] Verschuur, J., Koks, E. E., Hall, J. W., Observed impacts of the COVID-19 pandemic on global trade. Nature News, February $25 \quad 2021$. https://www.nature.com/articles/s41562-02101060-5.

[3] Team, T. I., What is a hedge fund? Investopedia, $\begin{array}{lll}\text { August } & 21 & 2021 .\end{array}$ https://www.investopedia.com/terms/h/hedgefund.a sp.

[4] Kooli, M., The diversification benefits of hedge funds and funds of hedge funds. Derivatives Use, Trading \& Regulation, Trading \& Regulation, 2007, vol 12, pp. 290-300. DOI: https://link.springer.com/article/10.1057/palgrave.d utr. 1850053.

[5] Centers for Disease Control and Prevention, 2009 H1N1 Pandemic. Centers for Disease Control and Prevention, June $11 \quad 2019$. https://www.cdc.gov/flu/pandemic-resources/2009h1n1-pandemic.html. 
[6] Bontschev, G., Eling, M., Factors that affect the performance of distressed securities hedge funds. Journal of Derivatives \& Hedge Funds, December 24 2013, vol 19, pp. 159-180. DOI: https://link.springer.com/article/10.1057/jdhf.2013. 12.

[7] BBC, The fiasco of the 1976, Swine Flu affair. BBC Future,

n.d.. https://www.bbc.com/future/article/20200918-thefiasco-of-the-us-swine-flu-affair-of-1976.

[8] World Health Organization., Severe acute respiratory syndrome (sars). World Health Organization, n.d.

https://www.who.int/health-topics/severe-acuterespiratory-syndrome\#tab=tab_1.

[9] Smith, L., Hedge fund operations during a pandemic, Hedge Fund Law Blog, November 142009.

https://hedgefundlawblog.com/tag/hedge-fundh1n1.

[10] Gregoriou, G. N., Hedge funds: A summary of the literature. Pensions: An International Journal, 2006, vol. 12, pp. 24-32. DOI: https://link.springer.com/article/10.1057/palgrave.p m.5950042. 